\title{
PENGARUH PENGALAMAN, INDEPENDENSI , DAN TIME BUDGET PRESSURE TERHADAP KUALITAS AUDIT DENGAN ETIKA SEBAGAI VARIABEL PEMODERASI (Studi Empiris pada Auditor di KAP Bandung)
}

\author{
Oleh \\ Enung Nurhayati \\ Universitas Kuningan \\ (enung21@yahoo.co.id)
}

\begin{abstract}
This researchexamine how ethics has an effect in moderating the Experience, Independence and Time Budget Pressure on Audit Quality.

Descriptive and verificative method is used in this research. The population in this study is the auditor who works at KAP Bandung, while the technique to determine the number of samples using the formula Yamane obtained 142 respondents . Questionnaires distributed for 142 respondents were returned by them are 74, while the questionnaire which can be further processed as many as 69. MRA( Moderated Regression Analysis) is used to analyze the data.

The result of this research show that experience, independence and time budget pressure simultaneously have an effect on audit quality. While, partially the experience and independence have a positive effect on audit quality, and time budget pressure has a negativeeffect on audit quality. Then,ethicshas a significant effect in moderating the experience, independence, and time budget pressure on audit quality.
\end{abstract}

Keywords :Experience, Independence,Time Budget Pressure, Ethics and Audit Quality.

\section{PENDAHULUAN}

Pemerintah Indonesia telah menyepakati untuk ikut serta dalam perdagangan bebas ASEAN (AFTA 2015) termasuk perdagangan jasa audit yang diberikan oleh auditor. Diberlakukannya AFTA 2015 ini menjadi tantangan bagi profesi auditor untuk dapat meningkatkan kualitas audit mereka agar dapat bersaing dengan para auditor dari negara-negara ASEAN.

Kualitas audit yang tinggi, memerlukan dua hal utama, yaitu auditor harus memiliki kompetensi dan independensi (Cristiawan, 2002). De Angelo (1981) mendefinisikan kualitas audit sebagai" probability that a given auditor will both (a) discover a breach in the client's accounting system, and (b) report the breach." Probabilitas penemuan suatu pelanggaran tergantung pada kemampuan teknikal auditor dan independensi auditor tersebut. Hal in sesuai dengan penelitianyang dilakukan oleh Goldman \& Barlev (1974); Nichols \& Price (1976) dalam Alim, dkk. (2007), mengasumsikan bahwa auditor dengan kemampuannya akan dapat menemukan suatu pelanggaran dan kuncinya adalah auditor tersebut harus independen. Tetapi tanpa informasi tentang kemampuan teknik (seperti pengalaman audit, pendidikan, profesionalisme, dan struktur audit perusahaan), kapabilitas dan independensi akan sulit dipisahkan.

Kualitas audit telah menjadi isu yang penting bagi berbagai pihak semenjak terungkapnya kasus Enron di Amerika yang melibatkan kantor akuntan publik Arthur Andersen. Di Indonesia sendiri terdapat beberapa kasus pelanggaran yang telah dilakukan baik oleh kantor akuntan publik maupun auditor 
yang melakukan penugasan audit. Berikut beberapa kasus keuangan yang menimpa banyak perusahaan yang ikut melibatkan kantor akuntan publik dan auditor baik di Indonesia maupun di luar negeri.

Tabel 1.1

Kasus Pelanggaran Kantor Akuntan Publik dan Auditor

\begin{tabular}{|c|c|c|c|}
\hline Nama Entitas & $\begin{array}{c}\text { Nama } \\
\text { KAP/Auditor }\end{array}$ & Pelanggaran & Sanksi \\
\hline 1 & 2 & 3 & 4 \\
\hline $\begin{array}{l}\text { Enron } \\
\text { (2001) }\end{array}$ & $\begin{array}{l}\text { KAP Arthur } \\
\text { Andersen }\end{array}$ & $\begin{array}{l}\text { KAP Arthur Andersen } \\
\text { membantu manajemen } \\
\text { Enron melakukan } \\
\text { manipulasi laporan } \\
\text { keuangan }\end{array}$ & $\begin{array}{l}\text { Pemerintah Amerika } \\
\text { membubarkan KAP } \\
\text { Arthur Andersen }\end{array}$ \\
\hline $\begin{array}{l}\text { Kimia Farma } \\
(2002)\end{array}$ & Auditor LSW & $\begin{array}{l}\text { KAP telah mengikuti } \\
\text { standar audit yang } \\
\text { berlaku namun gagal } \\
\text { mendeteksi kecurangan } \\
\text { yang dilakukan } \\
\text { manajemen Kimia } \\
\text { Farma dan terbukti } \\
\text { membantu manajemen } \\
\text { melakukan kecurangan } \\
\text { tersebut. }\end{array}$ & $\begin{array}{l}\text { Bapepam } \\
\text { memberikan sanksi } \\
\text { administratif kepada } \\
\text { auditor sebesar Rp } \\
100 \text { juta dan Kimia } \\
\text { Farma sebesar Rp } 500 \\
\text { juta }\end{array}$ \\
\hline $\begin{array}{l}\text { Great River, Tbk. } \\
\text { (2006) }\end{array}$ & Auditor JAS & $\begin{array}{l}\text { Auditor telah melakukan } \\
\text { pelanggaran terhadap } \\
\text { Standar } \\
\text { ProfesionalAkuntan } \\
\text { Publik (SPAP) berkaitan } \\
\text { dengan laporan audit } \\
\text { atas laporan keuangan } \\
\text { konsolidasiGreat River }\end{array}$ & $\begin{array}{l}\text { Pembekuan ijin } \\
\text { selama } 2 \\
\text { tahun oleh Menteri } \\
\text { Keuangan RI }\end{array}$ \\
\hline $\begin{array}{l}\text { PT. Angkasa } \\
\text { Wijaya, PT. } \\
\text { Ryorongkor, PT. } \\
\text { Pasaman, PT. } \\
\text { Merpati } \\
\text { (2009) }\end{array}$ & Auditor NA & $\begin{array}{l}\text { Auditor melakukan } \\
\text { pelanggaran terhadap } \\
\text { ketentuan pembatasan } \\
\text { masa pemberian jasa } \\
\text { audit terhadap PT . } \\
\text { Angkasa, PT. } \\
\text { Ryorongkor, PT. } \\
\text { Pasaman, PT. Merpati } \\
\end{array}$ & $\begin{array}{l}\text { Pembekuan ijin } \\
\text { selama } 6 \text { bulan oleh } \\
\text { Menteri Keuangan RI }\end{array}$ \\
\hline $\begin{array}{l}\text { PT. Data Scrip } \\
\text { (2009) }\end{array}$ & Auditor BN & $\begin{array}{l}\text { Auditor belum } \\
\text { sepenuhnya mematuhi } \\
\text { SPAP dalam } \\
\text { pelaksanaan audit umum } \\
\text { laporan keuangan } \\
\text { konsolidasian PT. Data } \\
\text { Scrip }\end{array}$ & $\begin{array}{l}\text { Pembekuan ijin } \\
\text { selama } 3 \text { bulan oleh } \\
\text { Menteri Keuangan RI }\end{array}$ \\
\hline $\begin{array}{l}\text { PT. Samcon } \\
\text { (2009) }\end{array}$ & Auditor HB & $\begin{array}{l}\text { Auditor belum } \\
\text { sepenuhnya mematuhi } \\
\text { SPAP dalam }\end{array}$ & $\begin{array}{l}\text { Pembekuan selama } 3 \\
\text { bulan oleh Menteri } \\
\text { Keuangan RI }\end{array}$ \\
\hline
\end{tabular}




\begin{tabular}{|l|l|l|}
\hline & $\begin{array}{l}\text { pelaksanaan audit umum } \\
\text { atas laporan keuangan } \\
\text { PT. Samcon }\end{array}$ & \\
\hline
\end{tabular}

\section{Sumber: Diolah dari berbagai sumber}

Dari beberapa kasus di atas, muncul pertanyaan "Apakah trik-trik rekayasa laporan keuangan mampu terdeteksi oleh auditor yang melakukan audit atas laporan keuangan tersebut atau sebenarnya telah terdeteksi namun auditor justru ikut mengamankan praktik kejahatan tersebut?" Tentu saja jika yang terjadi adalah auditor tidak mampu mendeteksi trik rekayasa laporan keuangan, maka yang menjadi inti permasalahannya adalah kurangnya pengalaman auditor dan adanya time budget pressure. Namun jika yang terjadi justru auditor ikut mengamankan praktik rekayasa tersebut, maka inti permasalahannya adalah independensi dan etika auditor tersebut. Terkait dengan konteks inilah, muncul pertanyaan apakah pengalaman, independensi, dantime budget pressure berpengaruh terhadap kualitas audit yang dihasilkan oleh auditor serta apakah etika dapat memoderasi pengaruh pengalaman, independensi, dantime budget pressureterhadap kualitas audit yang dihasilkan oleh auditor.

Guna menunjang profesionalisme nya sebagai auditor maka auditor dalam melaksanakan tugas audit harus berpedoman pada standar auditing yangditetapkan oleh Institut Akuntan Publik Indonesia (IAPI), yaitu standar umum, standar pekerjaan lapangan dan standar pelaporan. Standar umum merupakancerminan kualitas pribadi yang harus dimiliki oleh seorang auditor yangmengharuskan auditor untuk memiliki keahlian dan pelatihan teknis yang cukupdalam melaksanakan prosedur audit. Sedangkan standar pekerjaan lapangan danstandar pelaporan mengatur auditor dalam hal perencanaan audit yang meliputi pengumpulan data dan kegiatanlainnya yang dilaksanakan selama melakukan audit serta mewajibkan auditor untuk menyusun suatu laporan atas laporan keuangan yang diauditnya secarakeseluruhan (SPAP, 2011).

Dalam standar umum yang pertama ditegaskan bahwa betapapun tingginya kemampuan seseorang dalam bidang-bidang lain, termasuk dalam bidang bisnis dan keuangan, ia tidak dapat memenuhi persyaratan yang dimaksudkan dalam standar auditing tersebut, jika tidak memiliki pendidikan serta pengalaman memadai dalam bidang auditing. Seorang auditor juga harus selalu mengikuti perkembangan yang berkaitan dengan profesinya, seperti perkembangan standar akuntansi terbaru yaitu IFRS dan peraturan-peraturan pemerintah termasuk perpajakan. Pengalaman profesional dapat diperoleh dari praktek kerja di bawah bimbingan auditor yang lebih senior. Menurut Dwi Ermayanti (2010) bahwa pengalaman auditor (lebihdari 2 tahun) dapat menentukan profesionalisme, kinerja, komitmen terhadap organisasi, serta kualitas auditor melalui pengetahuan yang diperolehnya dari pengalaman melakukan audit.

Untuk menaikkan tingkat keandalan laporan keuangan suatu perusahaan maka auditor tidak hanya perlu memiliki pengalamansaja tetapi juga harus independen dalam pengauditan. Tanpa adanya independensi, auditor tidak berarti apa-apa. Atau dengan kata lain, keberadaan auditor ditentukan oleh independensinya. Standar umum kedua (SA seksi 220 dalam SPAP, 2011) menyebutkan bahwa "Dalam semua hal yang berhubungan dengan perikatan, independensi dalam sikap mental harus dipertahankan oleh auditor ". Standar ini mengharuskan auditoruntuk bersikap independen (tidak mudah dipengaruhi), karena ia melaksanakan pekerjaannya untuk kepentingan umum. Dengan demikian ia tidak dibenarkan untuk 
memihak kepada kepentingan siapa pun. Auditor harus melaksanakan kewajiban untuk bersikap jujur tidak hanya kepada manajemen dan pemilik perusahaan, namun juga kepada kreditur dan pihak lain yang meletakkan kepercayaan atas laporan keuangan auditan.

Faktor lain yang dapat mempengaruhi kualitas audit adalah time budget pressure (tekanan anggaran waktu). Menurut Waggoner et al. (1991) dalam Hutabarat (2012:2) jika alokasi waktu untuk penugasan tidak cukup maka auditor mungkin mengkompensasikan dengan kerja mereka dengan cepat, dan hanya menyelesaikan tugas-tugas yang penting saja sehingga mungkin menghasilkan kinerja yang tidak efektif. Dezoort (1998) dalam Hutabarat (2012:2) menyatakan bahwa hal yang umum ditemukan bahwa di bawah tekanan anggaran waktu, individu cenderung akan bekerja dengan cepat sehingga akan berdampak pada penurunan kinerjanya. Time budget pressureakan memberikan pengaruh yang negatif terhadap kualitas pekerjaan audit. Sebagian besar penelitian mengindikasikan bahwa time pressure dapat mendorong perilaku disfungsional antara lain terjadinya prematuresign-off dan underreporting of chargeable time (Margheim et.al(2005); Coram et. al (2001); Soobaroyen dan Chengabroyan, 2006). Time budget pressure dapat menyebabkan penurunan kualitas audit karena adanya time budget pressure dan time deadline pressure. Time budget pressure digunakan untuk menuntut auditor melakukan efesiensi waktu terhadap anggaran waktu yang telah disusun, hal ini terkait adanya pembatasan waktu yang sangat ketat.

Dalam menjalankan profesinya seorang auditor secara terus-menerus berhadapan dengan dilema etis yang melibatkan pilihan antara nilai-nilai yang bertentangan.Seorang auditor memiliki hubungan yang unik dengan pengguna jasanya jika dibandingkan dengan profesi lainnya. Profesi lain mendapatkan penugasan dari pengguna jasa dan bertanggung jawab juga kepadanya, sementara auditor mendapat penugasan dan memperoleh fee dari perusahaan yang menerbitkan laporan keuangan, namun bertanggung jawab kepada pengguna laporan keuangan. Hubungan yang unik ini sering kali menempatkan auditor pada situasi-situasi dilematis. Oleh sebab itu sangat penting bagi auditor untuk melaksanakan audit dengan menjunjung tinggi kode etik profesi akuntan publik, karena perilaku tidak etis saat ini merupakan isu yang relevan bagi profesi auditor. Di Indonesia, isu mengenai etika auditor berkembang seiring dengan terjadinya beberapa pelanggaran etika baik yang dilakukan oleh auditor independen, auditor intern, maupun auditor pemerintah (Maryani dan Ludigdo, 2001).

Pengembangan dan kesadaran etik atau moral memainkan peran kunci dalam semua area profesi akuntansi (Louwers, et al. dalam Alim, dkk., 2007). Dalam menjalankan profesinya sebagai auditor di Indonesia, etika auditor telah diatur dalam Kode Etik Profesi Akuntan Publik. Kode Etik Profesi Akuntan Publik berisikan prinsip dasar dan aturan etika profesi yang harus diterapkan oleh setiap individu dalam kantor akuntan publik (KAP) atau jaringan KAP baik yang merupakan anggota IAPI maupun yang bukan anggota IAPI yang memberikan jasa professional, meliputi jasa assurance maupun jasa selain assurance.

Banyak penelitian yang telah dilakukan dalam bidang auditing yang menunjukkan bahwa pengalaman, independensi, dan time budget pressure dari seorang auditor berpengaruh terhadap kualitas audit. Penelitian ini merupakan pengembangan dari penelitian yang dilakukan oleh Hutabarat (2012) dan Alim, dkk. (2007) dengan menambahkan variabel independen sebagai faktor yang mempengaruhi kualitas audit (independent variable) dan etika sebagai variabel pemoderasi, yaitu meneliti apakah pengalaman, independensi, dan time budget pressureauditor berpengaruh 
terhadap kualitas audit dan meneliti apakah etika memoderasi pengaruh pengalaman, independensi, dan time budget pressureterhadap kualitas audit.

\section{KAJIAN PUSTAKA DAN HIPOTESIS Kajian Pustaka}

\section{Pengalaman berpengaruh terhadap Kualitas Audit}

Pengalaman audit adalah pengalaman auditor dalam melakukan audit laporan keuangan baik dari segi lamanya waktu maupun banyaknya penugasan yang pernah ditangani. Seorang auditor yang memilikipengalaman yang memadai akan lebih memahami danmengetahui berbagai masalah secara lebih mendalam dan lebih mudah dalammengikuti perkembangan yang semakin kompleks dalam lingkungan auditkliennya.Abdolhammadi dan Wright (1987) memberikan bukti empiris bahwa dampak pengalaman auditor akan signifikan terhadap hasil kinerja auditor, mereka juga menyimpulkan bahwa staf yang berpengalaman akan memberikan pendapat yang berbeda dengan staf junior untuk tugas-tugas yang sifatnya terstruktur. Sementara Libby dan Frederick (1990) menyimpulkan bahwa semakin banyak pengalaman auditor semakin dapat menghasilkan berbagai dugaan dalam menjelaskan temuan audit. Penelitian serupa dilakukan oleh Tubbs (1992) menunjukkan bahwa subjek yang mempunyai pengalaman audit lebih banyak maka akan menemukan kesalahan yang lebih banyak dan item-item kesalahannya lebih besar dibandingkan auditor yang pengalaman auditnya lebih sedikit. Kompetensi auditor adalah auditor yang dengan pengetahuan dan pengalamannya yang cukup dan eksplisit dapat melakukan audit secara objektif, cermat dan seksama. Kualitas audit merupakan segala kemungkinan (probability) dimana auditor pada saat mengaudit laporan keuangan klien dapat menemukan pelanggaran yang terjadi dalam sistem akuntansi klien dan melaporkannya dalam laporan keuangan auditan, dimana dalam melaksanakan tugasnya tersebut auditor berpedoman pada standar auditing dan kode etik akuntan yang relevan. Oleh karena itu dapat dipahami bahwa seorang auditor yang memiliki pengalaman yang memadai akan lebih memahami dan mengetahui berbagai masalah secara lebih mendalam dan lebih mudah dalam mengikuti perkembangan yang semakin kompleks dalam lingkungan audit kliennya. Jadi, dari uraian penelitian di atas dapat disimpulkan bahwa pengalaman auditor berpengaruh terhadap kualitas audit, semakin lama pengalaman yang dimiliki auditor maka semakin tinggi pula kualitas audit yang dihasilkannya. Hal ini didukung penelitian yang dilakukan oleh Andini Ika Setyorini; Hutabarat (2012); Alim (2007); Richard M Tubbs (1992); De Angelo (1981); Sarah E. Bonner \& Bary L. Lewis (1990), bahwa pengalaman akan berpengaruh positif dan signifikan terhadap kualitas audit. Penelitian tersebut tidak didukung oleh Achmad Badjuri (2011) dan Icuk Rangga Bawono \& Elisha Muliani singgih (2010) yang menyimpulkan bahwa pengalaman tidak berpengaruh terhadap kualitas audit.

\section{Independensi berpengaruh terhadap Kualitas Audit. \\ Independensi merupakan sikap yang} diharapkan dari seorang auditor untuk tidak mempunyai kepentingan pribadi dalam melaksanakantugasnya. Oleh karena itu cukuplah beralasan bahwa untuk menghasilkan audit yangberkualitas diperlukan sikap independen dari auditor. Karena jika auditor kehilangan independensinya maka laporan audit yang dihasilkan tidak sesuai dengan kenyataan yang ada sehingga tidak dapat digunakan sebagai dasar pengambilan keputusan. Kualitas audit merupakan segala kemungkinan (probability) dimana auditor pada saat mengaudit laporan keuangan klien dapat menemukan pelanggaran yang terjadi dalam sistem akuntansi klien dan melaporkannya dalam laporan keuangan 
auditan, dimana dalam melaksanakan tugasnya tersebut auditor berpedoman pada standar auditing dan kode etik profesi akuntan publik yang relevan. Oleh karena itu dapat dipahami bahwa seorang auditor yang memiliki independensi yang memadai akan lebih dapat mengungkapkan kecurangan yang terjadi pada kliennya. Jadi, dari uraian penelitian di atas dapat disimpulkan bahwa independensi auditor berpengaruh terhadap kualitas audit, semakin independen auditor maka semakin tinggi pula kualitas audit yang dihasilkannya. Banyak penelitian yang telah dilakukan berkaitan dengan pengaruh independensi terhadap kualitas audit yang hasilnya adalah bahwa independensi berpengaruh positif dan signifikan terhadap kualitas audit, seperti diantaranya penelitian yang dilakukan oleh Alim (2007);Achmad Badjuri (2011); Icuk Rangga Bawono, Elisha Muliani Singgih (2010); Christiawan (2002); dan Payamta (2006).

\section{Time Budget Pressure berpengaruh terhadap Kualitas Audit}

Auditor menetapkan alokasi waktu audit yang sangat ketat tetapi akibatnya memiliki efek samping yang merugikan publik, yaitu memunculkan perilaku yang mengancam kualitas audit, antara lain penurunan tingkat pendeteksian dan penyelidikan aspek kualitatif salah saji, gagal meneliti prinsip akuntansi, melakukan review dokumen secara dangkal, menerima penjelasan klien secara lemah dan mengurangi pekerjaan pada salah satu langkah audit di bawah tingkat yang diterima. Hal ini menunjukkan adanya pengaruh negatif time budget pressure terhadap kualitas audit. Sebagian besar penelitian mengindikasikan bahwa tekanan waktu bisa mendorong perilaku disfungsional antara lain terjadinya premature sign off dan under-reporting of time. Tekanan anggaran waktu menyebabkan menurunnya efektivitas dan efesiensi kegiatan pengauditan. Kualitas audit bisa semakin buruk, bila alokasi waktu yang dianggarkan tidak realistis dengan kesulitan audit yang diembannya. Banyak penelitian yang telah dilakukan berkaitan dengan pengaruh time budget pressure terhadap kualitas audit, yang menghasilkan pengaruh negatif yaitu bahwa semakin tinggi tekanan anggaran waktu maka akan semakin menurun kualitas auditnya, seperti penelitian yang dilakukan oleh Hutabarat (2012); dan Paul Coram, Juliana $\mathrm{Ng}$ and David Woodliff (2001); Soobaroyen \& Chengabroyan (2005); Dezoort (1998).

\section{Etika memoderasi pengaruh pengalaman terhadap kualitas audit}

Behn et al (1997) dalam Widagdo et al. (2002) mengembangkan atribut kualitas audit yang salah satunya adalah standard etika yang tinggi, sedangkan atribut-atribut lainnya terkait dengan kompetensi auditor yang salah satunya adalah pengalaman akuntan publik. Audit yang berkualitas sangat penting untuk menjamin bahwa auditor memenuhi tanggung jawabnya kepada investor, masyarakat umum dan pemerintah serta pihak-pihak lain yang mengandalkan kredibilitas laporan keuangan yang telah diaudit, dengan menegakkan etika yang tinggi.

\section{Etika memoderasi pengaruh independensi terhadap kualitas audit}

Menurut Nichols dan Price (1976) dalam Alim (2007) menemukan bahwa ketika auditor dan manajemen tidak mencapai kata sepakat dalam aspek kinerja, maka kondisi ini dapat mendorong manajemen untuk memaksa auditor melakukan tindakan yang melawan standar, termasuk dalam pemberian opini. Kondisi ini akan sangat menyudutkan auditor sehingga kemungkinan bahwa auditor akan melakukan apa yang diinginkan oleh pihak manajemen.Deis dan Giroux (1992) juga mengatakan bahwa pada konflik kekuatan, klien dapat menekan auditor untuk melawan standar profesional dan dalam ukuran yang besar, kondisi keuangan klien yang sehat dapat 
digunakan sebagai alat untuk menekan auditor dengan cara melakukan pergantian auditor. Hal ini dapat membuat auditor tidak akan dapat bertahan dengan tekanan klien tersebut sehingga menyebabkan independensi mereka melemah. Posisi auditor juga sangat dilematis dimana mereka dituntut untuk memenuhi keinginan klien namun di satu sisi tindakan auditor dapat melanggar standar profesi sebagai acuan kerja mereka. Hipotesis dalam penelitian mereka terdapat argumen bahwa kemampuan auditor untuk dapat bertahan di bawah tekanan klien mereka tergantung dari kesepakatan ekonomi, lingkungan tertentu, dan perilaku termasuk di dalamnya mencakup etika profesional.

6. Etika memoderasi pengaruh Time Budget Pressure terhadap Kualitas Audit.

Anggaran waktu dianggap sebagai faktor timbulnya kerja audit di bawah standar dan mendorong terjadinya pelanggaran terhadap standar audit dan perilaku-perilaku yang tidak etis (Azad 1994 dalam Hutabarat (2012)). Gaya evaluasi yang berorientasi pada budget umumnya menekankan pada target-target biaya dan waktu yang terkadang mengorbankan kualitas (Pierce dan Sweeney, 2004 dalam Hutabarat (2012)). Adanya pengendalian yang ketat untuk aturan dan prosedur suatu pekerjaan tentunya akan berpengaruh pada kinerja dan akan menciptakan stres bagi auditor ditambah dengan time budget yang tidak realistis sehingga kemungkinan kualitas audit menjadi diragukan, yang berakibat munculnya dysfunctional behaviors. Hal tersebut sesuai dengan riset Coram (2001) yang menunjukkan bahwa terdapat penurunan kualitas audit pada auditor yang mengalami tekanan dikarenakan anggaran waktu yang sangat ketat. Dari beberapa pendapat diatas disimpulkan bahwa time budget pressure berpengaruh pada penurunan kualitas audit.

\section{Hipotesis}

$\left.\mathbf{( H}_{\mathbf{1}}\right)$ Pengalaman, independensi, dan time budget pressurememiliki pengaruh secara simultanterhadapkualitas audit.

$\left.\mathbf{H}_{2}\right)$ Pengalaman, independensi, dan time budget pressurememiliki pengaruh secara parsialterhadapkualitas audit.

(H) Etika profesi memoderasi pengaruh pengalamanterhadapkualitas audit.

(H4) Etika profesi memoderasi pengaruh independensiterhadap kualitas audit.

(H5) Etika profesi memoderasi pengaruh time budget pressure
terhadapkualitas audit.

\section{METODE PENELITIAN}

Penelitian ini bertujuan untuk memperoleh gambaran atau deskripsi mengenai pengaruh pengalaman, independensi dan time budget pressure terhadap kualitas audit dengan etika profesi sebagai variabel pemoderasi. Sesuai dengan tujuan yang ingin dicapai, maka digunakan dua jenis metode penelitian yaitu Deskriptif dan Verifikatif.

\section{Populasi dan Sampel}

Populasi dalam penelitian ini adalah auditor yang bekerja pada Kantor Akuntan Publik di Bandung.Berdasarkan data dariDirektori Kantor Akuntan Publik dan Akuntan Publik 2013 terdapat 28 Kantor Akuntan Publik di Bandung sedangkan berdasarkan data dari Pusat Pembinaan Akuntan dan Jasa Penilai (PPAJP) jumlah auditor adalah 219 orang. Responden dalam penelitian ini adalah auditordengan kriteria bahwa auditor tersebut bekerja pada kantor akuntan publik yang masih aktif dan auditor dimana ia menjalankan proses audit, yaitu yang melakukan audit terhadap laporan keuangan. Alasan pemilihan tersebut adalah auditor melakukan pemeriksaan terhadap laporan keuangan dan memberikan pendapat atas dasar hasil 
pemeriksaan tersebut, sehingga mereka terlibat dalam penentuan kualitas audit.

Teknik penentuan jumlah sampel dilakukan dengan menggunakan rumus Yamane (Israel, 1992)dengan presisi 5\% diperoleh jumlah sampel sebanyak 142 orang.Pengambilan sampel dalam penelitian ini menggunakan cararandom sampling berdasarkan pertimbangan (judgment).

Persamaan untuk uji hipotesis 1 \&2:

$Y=a+b_{1} X_{1}+b_{2} X_{2}+b_{3} X_{3}+e$

Dimana : $\mathrm{Y}=$ variabel dependen, kualitas audit

$$
\begin{aligned}
& \mathrm{a}=\text { intersep } / \text { konstanta } \\
& \mathrm{b}=\text { slope } / \text { koefisien regresi }
\end{aligned}
$$
variabel independen $\mathrm{X} 1=$ Pengalaman

$$
\begin{aligned}
& \mathrm{X} 2=\text { Independensi } \\
& \mathrm{X} 3=\text { Time Budget Pressure } \\
& \mathrm{e} \quad=\text { standar error }
\end{aligned}
$$

Persamaan untuk uji hipotesis 3,4, \& 5

$$
\begin{aligned}
& \mathrm{EP}(\mathrm{Z})=\mathrm{a}+\mathrm{bP}(\mathrm{X})+\mathrm{e} \ldots \ldots \ldots \ldots . .(1) \\
& \mathrm{e}=|| \mathrm{a}+\mathrm{b} \text { Kualitas Audit }
\end{aligned}
$$

\section{HASIL PENELITIAN \\ Hasil Penelitian \\ Data Responden}

Data penelitian dikumpulkan dengan mengirimkan sebanyak 142 kuesioner.Jumlah kuesioner yang kembali sebanyak 74 kuesioner, sedangkan kuesioner yang dapat dioleh sebanyak 69 kuesioner.Adapun tingkat pengiriman dan pengembalian ditunjukkan pada tabel 1.2.

Tabel 1.2

Tingkat Pengembalian Kuesioner

\begin{tabular}{|l|c|}
\hline \multicolumn{1}{|c|}{ Keterangan } & Jumlah \\
\hline Jumlah kuesioner & 142 \\
\hline Kuesioner yang tidak kembali & 68 \\
\hline Kuesioner yang terkumpul & 74 \\
\hline Kuesioner yang didrop & 5 \\
\hline Kuesioner yang dipakai dalam pengolahan data & 69 \\
\hline Tingkat pengembalian (respon rate) & $52,1 \%$ \\
\hline
\end{tabular}

Sumber: Data Kuesioner

\section{Uji Validitas, Reliabilitas, dan Uji Asumsi} Klasik

Pengujian instrument penelitian baik dari segi validitas maupun reliabilitasnya terhadap 69 responden diperoleh hasilbahwa instrument penelitian yang dipergunakan adalah valid dengan $r_{\text {hitung }}>r_{\text {tabel }} \quad\left(r_{\text {hitung }}>0,232\right)$ dan reliabel dengan nilai Cronbach's Alpha memiliki nilai lebih besar dari 0,70 (Nunnally,1994 dalam Ghozali, 2011). Dalam penelitian ini, uji asumsi klasik dilakukan atas tiga variabel independen, yaitu pengalaman, independensi, dan time budget pressure, dan juga variabel dependen yaitu kualitas audit serta etika profesi sebagai variabel pemoderasi. Dalam penelitian ini, model lolos dari uji asumsi klasik seperti normalitas, multikolinearitas, heteroskedastisitas, dan autokorelasi.

\section{Analisis Regresi Berganda}

$$
\mathrm{Y}=21,521+0,580 \mathrm{X}_{1}+1,263 \mathrm{X}_{2}-1,235 \mathrm{X}_{3}+\varepsilon
$$

sebesar 21,521 berarti bahwa dengan asumsi variabel pengalaman $\left(\mathrm{X}_{1}\right)$, independensi $\left(\mathrm{X}_{2}\right)$ dan time budget pressure $\left(\mathrm{X}_{3}\right)$ dianggap konstan atau sama dengan nol, maka besarnya kualitas audit (Y) akan bernilai 21,521. Koefisien regresi untuk variabel $\mathrm{X}_{1}$ positif, menunjukkan adanya hubungan yang searah antara pengalaman $\left(\mathrm{X}_{1}\right)$ dengan kualitas audit $(\mathrm{Y})$. Koefisien regresi variabel $\mathrm{X}_{1}$ yang positif mengandung arti bahwa pengalaman auditorakan meningkatkan kualitas audit. Koefisien regresi untuk 
variabel $\mathrm{X}_{2}$ positif, menunjukkan adanya hubungan yang searah antara independensi $\left(\mathrm{X}_{2}\right)$ dengan kualitas audit $(\mathrm{Y})$. Koefisien regresi variabel $\mathrm{X}_{2}$ yang positif mengandung arti bahwa independensi auditorakan meningkatkan kualitas audit.Koefisien regresi untuk variabel $\mathrm{X}_{3}$ negatif, menunjukkan adanya hubungan yang tidak searah antara time budget pressure $\left(\mathrm{X}_{3}\right)$ dengan kualitas audit $(\mathrm{Y})$. Koefisien regresi variabel $\mathrm{X}_{3}$ yang negatif mengandung arti bahwa time budget pressureakan menurunkan kualitas audit.

\section{Hasil Uji Hipotesis 1 dan 2}

Uji Hipotesis 1, berdasarkan hasil uji $\mathrm{F}$ diperoleh $\mathrm{F}_{\text {hitung }}$ sebesar 35,509 dengan $p$-value sebesar 0,000 . Oleh karena $p$-valuelebih kecil dari nilai $\alpha$ yang telah ditetapkan yaitu 0,05, maka dapat disimpulkan bahwa variabel bebas (pengalaman, independensi, dan time budget pressure) secara simultan berpengaruh signifikan terhadap variabel tidak bebas (kualitas audit) pada tingkat kepercayaan $95 \%$ atau hipotesis pertama $\left(\mathrm{H}_{1}\right)$ diterima.

\section{Uji Hipotesis 2,}

Berdasarkan uji $\mathrm{t}$ semua variabel independen, yaitu pengalaman, independensi, dan time budget pressure diperoleh nilai $t_{\text {hitung }}>t_{\text {tabel }}$ ( $t_{\text {hitung }}>1,6686$ ), sehingga dapat dikatakan bahwa terdapat pengaruh secara parsial antara pengalaman, independensi, dan time budget pressure terhadap kualitas audit pada tingkat kepercayaan $95 \%$ atau hipotesis kedua $\left(\mathrm{H}_{2}\right)$ diterima.

\section{Hasil Uji Hipotesis 3, 4, dan 5}

Berdasarkan hasil uji Moderated Regression Analysis (MRA) dengan uji residual bahwa hipotesis ketiga, keempat, dan kelima diterima, yaitu etika profesi memoderasi pengaruh pengalaman, independensi, dan time budget pressure terhadap kualitas audit.

Uji Hipotesis 3, diperoleh hasil uji residual persamaan regresi (2) sebagai berikut :

Coefficients $^{\mathrm{a}}$

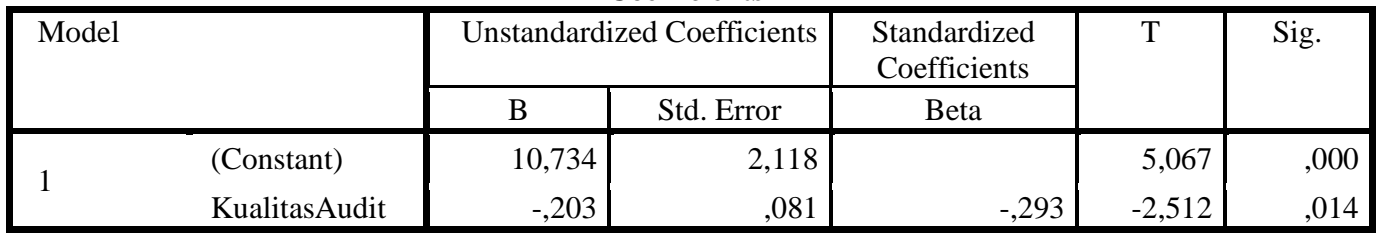

a. Dependent Variable: AbsRes_1

Sumber : lampiran hasil output SPSS 20.0

Berdasarkan output SPSS di atas bahwa koefisien regresi pada variabel kualitas audit sebesar -0,203 dengan nilai $\mathrm{t}$ hitung sebesar -2,512 lebih kecil dari pada $\mathrm{t}$ tabel sebesar $-1,6686$ atau nilai sig. $(0,014)$ lebih kecil dari $\alpha(0,05)$ dengan arah negatif,maka dapat disimpulkan bahwa variabel etika profesi memoderasi pengaruh pengalaman terhadap kualitas audit atau hipotesis $\left(\mathrm{H}_{3}\right)$ diterima.

Uji Hipotesis 4, diperoleh hasil uji residual persamaan regresi (2) sebagai berikut :

Coefficients $^{\mathrm{a}}$

\begin{tabular}{|c|c|c|c|c|c|c|}
\hline \multirow{2}{*}{\multicolumn{2}{|c|}{ Model }} & \multicolumn{2}{|c|}{$\begin{array}{l}\text { Unstandardized } \\
\text { Coefficients } \\
\end{array}$} & $\begin{array}{r}\text { Standardized } \\
\text { Coefficients }\end{array}$ & \multirow[t]{2}{*}{$\mathrm{T}$} & \multirow[t]{2}{*}{ Sig. } \\
\hline & & B & Std. Error & Beta & & \\
\hline \multirow{2}{*}{1} & (Constant) & 11,439 & 2,381 & & 4,803 & ,000 \\
\hline & KualitasAudit &,- 230 & 091, &,- 295 & $-2,525$ & ,014 \\
\hline
\end{tabular}

a. Dependent Variable: AbsRes_2

Sumber : lampiran hasil output SPSS 20.0
Berdasarkan output SPSS di atas diperoleh koefisien regresi pada variabel 
kualitas audit sebesar -0,230 dengan nilai $\mathrm{t}$ hitung sebesar -2,525 lebih kecil dari pada $\mathrm{t}$ tabel sebesar -1,6686 atau nilai sig. $(0,014)$ lebih kecil dari $\alpha(0,05)$ dengan arah negatif,maka dapat disimpulkan bahwa variabel etika profesi memoderasi pengaruh independensi terhadap kualitas audit atau hipotesis $\left(\mathrm{H}_{4}\right)$ diterima.

Uji Hipotesis 5, diperoleh hasil uji residual persamaan regresi (2) sebagai berikut :

Coefficients $^{\mathrm{a}}$

\begin{tabular}{|c|c|c|c|c|c|c|}
\hline \multirow{2}{*}{\multicolumn{2}{|c|}{ Model }} & \multicolumn{2}{|c|}{$\begin{array}{l}\text { Unstandardized } \\
\text { Coefficients }\end{array}$} & $\begin{array}{c}\text { Standardized } \\
\text { Coefficients }\end{array}$ & \multirow[t]{2}{*}{$\mathrm{T}$} & \multirow[t]{2}{*}{ Sig. } \\
\hline & & B & Std. Error & Beta & & \\
\hline & (Constant) & 10,396 & 2,169 & & 4,792 & ,000 \\
\hline & KualitasAudit &,- 193 & ,083 &,- 2 & $-2,325$ & ,023 \\
\hline
\end{tabular}

a. Dependent Variable: AbsRes_3

Sumber : lampiran hasil output SPSS 20.0

Berdasarkan output SPSS di atas diperoleh koefisien regresi pada variabel kualitas audit sebesar -0,193 dengan nilai t hitung sebesar -2,325 lebih kecil dari pada $\mathrm{t}$ tabel sebesar $-1,6686$ atau nilai sig. $(0,023)$ lebih kecil dari $\alpha(0,05)$ dengan arah negatif,maka dapat disimpulkan bahwa variabel etika profesi memoderasi pengaruh time budget pressure terhadap kualitas audit atau hipotesis $\left(\mathrm{H}_{5}\right)$ diterima.

\section{Koefisien Determinasi $\left(\mathbf{R}^{\mathbf{2}}\right)$}

Besarnya pengaruh penerapan pengalaman, independensi dan time budget pressure terhadap kualitas audit ditunjukkan oleh nilai koefisien determinasi untuk model regresi yang diperoleh. Hasil perhitungan koefisien determinasi $\left(\mathrm{R}^{2}\right)$ besarnya adjusted $\mathrm{R}^{2}$ adalah 0,604 , hal ini berarti $60,4 \%$ variasi kualitas audit dijelaskan oleh variasi dari ketiga variabel independen yaitu pengalaman, independensi, dan time budget pressure. Sedangkan sisanya $39,6 \%$ dijelaskan oleh faktor lain diluar model.

\section{KESIMPULAN DAN SARAN \\ Kesimpulan}

1. Pengalaman, independensi, dan time budget pressure berpengaruh secara simultan dan signifikan terhadap kualitas audit.

2. Pengalaman, berpengaruh positif dan signifikan terhadap kualitas audit; independensi berpengaruh positif dan signifikan terhadap kualitas audit; serta time budget pressure berpengaruh negatif dan signifikan terhadap kualitas audit.

3. Etika profesi memoderasi pengaruh pengalaman terhadap kualitas audit.

4. Etika profesi memoderasi pengaruh independensi terhadap kualitas audit.

5. Etika profesi memoderasi pengaruh time budget pressure terhadap kualitas audit.

\section{Saran}

1. Bagi Kantor Akutan Publik diharapkan:

a. Dapat memberikan penugasan audit yang memiliki kompleksitas tugas audit yang tinggi kepada auditor yang sudah memiliki pengalaman audit, baik pengalaman dari sisi lama melakukan audit maupun dari sisi jumlah klien yang diaudit serta jenis perusahaan yang diaudit.

b. Dapat memperhatikan penyusunan rencana anggaran auditnya baik dalam hal anggaran waktu audit maupun penyusunan rencana anggaran biaya audit sehingga dalam pelaksanaan audit tidak akan mengalami tekanan anggaran waktu yang berlebihan yang dapat mengancam kualitas audit. 
2. Bagi auditor yang mendapatkan penugasan audit dari kliennya diusahakan untuk dapat benar-benar independen, tidak mendapat tekanan dari klien, tidak memiliki sikap keberpihakan baik terhadap klien maupun pihak pengguna laporan keuangan sehingga dalam melaksanakan penugasan auditnya dapat benar-benar objektif dan dapat menghasilkan audit yang berkualitas.

3. Bagi peneliti selanjutnya diharapkan agar dapat meneliti faktor-faktor lainnya yang berpengaruh terhadap kualitas audit yang belum diteliti pada penelitian ini, seperti motivasi, due professional care dan perencanaan audit.

\section{DAFTAR PUSTAKA}

Alvin A. Arens, Randal J. Elder, Mark S. Beasley. 2010. "Auditing and Assurance Services." Pearson Prentice Hall.

Behn, B.K..Carcello J.V. Hermanson D.R and Hermanson R.H.1997. "The determinants of audit clients satisfaction among clients of big 6 firms. "Accounting Horizon. Vol.11

Bonner, S. E. 1990. "Experience Effect in Auditing: The Role of Task Spesific Knowledge."The

Accounting Review.January.

Bonner, S.E. and B. L. Lewis. 1990. "Determinants of Auditor Expertise." Journal Accounting Research (Supplement)

Christiawan, Yulius Jogi. 2002. "Kompetensi dan Independensi Akuntan Publik:Refleksi HasilPenelitian Empiris. 'Jurnal Akuntansi dan Keuangan Vol.4No. 2 (Nov) Hal. 79-92

Cooper, Donald R \& Schindler, Pamela S. 2008.Businees Research Method. New York : McGraw-Hill.

De Angelo. 1981. "Auditor Size and Audit Quality." Journal of Accounting and
Economics 3, 183-199 NorthHolland Publishing Company

Direktori KAP dan Akuntan Publik, 2013. http://www.iapi.co.id

Donald R. Deis, Jr and Gary A. Giroux. 1992. "Determinants of Audit Quality in Public Sector"

Duff, A. 2004. "Auditqual: Dimension of Audit Quality."The Institute of Chartered Accountants of Scotland.

ErmayantiDwi, 2010. Batas Waktu, "Pengetahuan Akuntansi \& Audit, Pengalaman Pada Kualitas Audit"

Ghozali Imam. 2011. "Aplikasi Analisis Multivariate dengan Program SPSS" Badan Penerbit Universitas Diponegoro, Semarang

Gujarati, Damodar N. 2010. Basic Ekonometrica. $4^{\text {th }}$ Edition. New York. Mc Graw Hill.

Hamilton, J. Ruddock, C., Stokes, D., \& Taylor, S. 2005. "Audit Partner Rotation, Earnings Quality and Earnings Conservtism."

http://www.ssrn.com/sol3/papers.cfm?abstra ct id $=740846$

Hutabarat Goodman. 2012Vol. 6 No. 1, Januari. "Pengaruh Pengalaman, Time Budget Pressure dan Etika Auditor terhadap Kualitas Audit." Jurnal Ilmiah ESAI.

IAPI. 2011. "Standar Profesi Akuntan Publik." Jakarta. Salemba Empat.

Israel, Glenn D. 1992. Determining Sample Size.University of Florida, melalui.http://edis.ifas.ufl.edu.

Keputusan Ketua Badan Pengawas Pasar Modal dan Lembaga Keuangan Nomor: KEP-134/BL/2006 tentang Kewajiban penyampaian laporan tahunan bagi emiten atau perusahaan publik

Libby, R. and Joan Luft. 1993. "Determinants of Judgment Performance in Accounting Settings: Ability, Knowledge, Motivation, and Environment." Accounting, Organizations, and Society. July. 
Loren Margheim, Tim Kelley, Diane Pattison. 2005. "An Empirical Analysis of The Effects of Auditor Time Budget Pressure and Time Deadline Pressure.'"The Journal of Applied Business ResearchWinter.Vol 21. Np.1

Maryani, T. dan U. Ludigdo. 2001. "Survei Atas Faktor-faktor yang Mempengaruhi Sikap dan Perilaku Etis Akuntan."TEMA.Volume II Nomor 1.Maret. p. 49-62.

M. Nizarul Alim, Trisni Hapsari, Liliek Purwanti. 2007. "Pengaruh Kompetensi dan Independensi terhadap Kualitas Audit dengan Etika Auditor sebagai Variabel Moderasi." SNA X.

Mohammad Abdolhammadi and Arnold Wright. 1987. "An Examination of Effects of Experience and Task complexity on Audit Judgment"

Paul Coram, Juliana $\mathrm{Ng}$ and Davis Woodliff. 2001. "The Effects of Time Budget Pressure and Risk of Error on Auditor Performance." Department of Accounting and Finance, The University of Western Australia.

Payamta, 2006. "Pengaruh Kualitas Auditor, Independensi, dan Opini Audit Terhadap Kualitas Laporan Keuangan".Jurnal Bisnis \& Manajemen Vol. 6, No. 1.

Richard M. Tubbs. 1992. "The Effect of Experience on The Auditor's Organization and Amount of Knowledge."

Riduwan.2013 Cetakan Kesembilan. Metode dan Teknik Penyusunan Thesis, Bandung : Alfabeta.

Rochaety Ety, dkk.2007. "Metodologi Penelitian Bisnis dengan Aplikasi SPSS. "Mitra Wacana Media.

Said, Samsuar. 2006. Menkeu Bekukan Izin Akuntan Publik Justinus Aditya.http://www.depkeu.go.id/Ind/
News/NewsControl.asp?cdcate $=\mathrm{SP}$

AkuntanPublik.(28Nopember 2006)

Sarah E. Bonner and Barry L. Lewis. 1990. "Experience Effect in Auditing: The Role of Task Spesific Knowledge"

Sekaran Uma and Roger Bougie. 2010 Fifth Edition. "Research Methods for Business." John Wiley \& sons Ltd, The Atrium, Southern Gate, Chichester, West Sussex, PO19 8SQ. United Kingdom.

SinisukaErmayati. 2011." Pengaruh Tekanan Anggaran Waktu terhadap Kualtas Audit melalui Perilaku Pengurangan Pelaporan Waktu (underreporting of time) pada BPK RI'.Tesis Maksi Unpad.

Simamora, Henry.2002. Auditing. Yogyakarta : UPP AMP YKPN

Siti Kurnia Rahayu, Ely Suhayati. 2010. "Auditing: Konsep Dasar dan Pedoman Pemeriksaan Akuntan Publik." Graha Ilmu Yogyakarta

Suliyanto.2011. Ekonometrika Terapan: Teori \& Aplikasi dengan SPSS. CV. Andi Offset Yogyakarta

Teerooven Soobaroyen, Chelven Chengabroyan. 2006, Vol. 10, No. 3, pp. 201-218, November. "Auditors' Perceptions of Time Budget Pressure, Premature Sign Offs and Under-Reporting of Chargeable Time: Evidence from a Developing Country." International Journal of Auditing,

UmarHusein. 2008. Desain Penelitian Akuntansi Keperilakuan. Jakarta : PT Raja Grafindo Persada.

Widagdo, R. D. 2002. "Analisis Pengaruh Atribut-Atribut Kualitas Audit terhadap Kepuasan Klien.'Makalah Simposium Nasional Akuntansi 5. Semarang.

Wooten, T. C. 2003. "It is impossible to know the number of poor-quality audits." CPA Journal.January 